University of Nebraska - Lincoln

DigitalCommons@University of Nebraska - Lincoln

Agronomy \& Horticulture - Faculty Publications

Agronomy and Horticulture Department

1995

\title{
Modeling the Population Dynamics and Economics of Velvet leaf (Abutilon theophrasti) control in a Corn (Zea mays)-Soybean (Glycine max) Rotation
}

John L. Lindquist

University of Nebraska-Lincoln, jlindquist1@unl.edu

Bruce D. Maxwell

Montana State University

Douglas D. Buhler

University of Minnesota

Jeffrey L. Gunsolus

University of Minnesota

Follow this and additional works at: https://digitalcommons.unl.edu/agronomyfacpub

Part of the Plant Sciences Commons

Lindquist, John L.; Maxwell, Bruce D.; Buhler, Douglas D.; and Gunsolus, Jeffrey L., "Modeling the Population Dynamics and Economics of Velvet leaf (Abutilon theophrasti) control in a Corn (Zea mays)Soybean (Glycine max) Rotation" (1995). Agronomy \& Horticulture -- Faculty Publications. 618. https://digitalcommons.unl.edu/agronomyfacpub/618

This Article is brought to you for free and open access by the Agronomy and Horticulture Department at DigitalCommons@University of Nebraska - Lincoln. It has been accepted for inclusion in Agronomy \& Horticulture -Faculty Publications by an authorized administrator of DigitalCommons@University of Nebraska - Lincoln. 


\title{
Modeling the Population Dynamics and Economics of Velvetleaf (Abutilon theophrasti) Control in a Corn (Zea mays)-Soybean (Glycine max) Rotation ${ }^{1}$
}

\author{
JOHN L. LINDQUIST, BRUCE D. MAXWELL, DOUGLAS D. BUHLER, and JEFFREY L. GUNSOLUS ${ }^{2}$
}

Abstract. A simulation model was developed to predict the population dynamics and economics of velvetleaf control in a corn-soybean rotation. Data compiled from the literature were used to parameterize the model for two situations, one in which velvetleaf was infected by a Verticillium spp. wilt and one without infection. Verticillium was assumed to have no effect on corn or soybean yield. In the absence of control, simulated seedbank densities of a Verticillium-infected velvetleaf population were 5 to 50 times lower than for an uninfected velvetleaf population. The model was used to evaluate a threshold weed management strategy under the assumption that velvetleaf was the only weed and bentazon the only herbicide available for its control. In the absence of Verticillium, an economic optimum threshold of 2.5 seedlings $100 \mathrm{~m}^{-2}$ afforded the highest economic returns after $20 \mathrm{yr}$ of simulation. Simulations in which velvetleaf was infected in 8 out of 20 randomly assigned years indicated a $6 \%$ increase in annualized net return and an $11 \%$ reduction in the number of years that control was necessary. Sensitivity analysis indicated the parameter estimates having the greatest impact on economic optimum threshold were seedling emergence and survival, maximum seed production, and herbicide efficacy. Under an economic optimum threshold of 2.5 seedlings 100 $\mathbf{m}^{-2}$, management practices that manipulate the most sensitive demographic processes increased annualized net return by up to $13 \%$ and reduced long-term herbicide use by up to $26 \%$. Results demonstrate that combining an economic optimum threshold with alternative weed management strategies may increase economic return and reduce herbicide use. Nomenclature: Bentazon [3-(1-methylethyl)-(1H)-2,1,3-benzothiadiazin-4(3H)-one 2,2-dioxide]; velvetleaf, Abutilon

\footnotetext{
${ }^{1}$ Received for publication May 18, 1994, and in revised form December 8, 1994. Contribution No. 21,187 from the Minnesota Agric. Exp. Stn., St. Paul, MN 55108.

${ }^{2}$ Former Grad. Res. Asst., Dep. Agron. Plant Gen., Univ. Minnesota, St. Paul, MN 55108; Asst. Prof., Plant, Soil, and Environ., Sci. Dept., Montana State Univ. Bozeman, MT 59717; Res. Agron., U.S. Dept. Agric., Agr. Res. Serv., National Soil Tilth Lab., Ames IA 50011; and Assoc. Prof., Dept. Agron. and Plant Gen., Univ. Minnesota, St. Paul, MN 55108. Current address of first author: Dep. Agron., Univ. Nebraska, Lincoln NE 68583.

${ }^{3}$ Letters following this symbol are a WSSA-approved computer code from Composite List of Weeds, Revised 1989. Available from WSSA, 1508 West University Ave., Champaign, IL 61821-3133.

${ }^{4}$ Abbreviations: ANR, annualized net return; EOT, economic optimum threshold; ER, economic return; $\mathrm{N}_{\mathrm{m}}$, mature velvetleaf population density; $\mathrm{N}_{\mathrm{p}}$, seed production; $\mathrm{N}_{\mathrm{sb}}$, seedbank density; $\mathrm{N}_{\mathrm{sl}}$, seedling density; $\mathrm{N}_{\mathrm{T}}$, threshold seedling density; $\mathrm{q}$, binary term; $\mathrm{Q}$, sensitivity coefficient; t, time; YL, percent crop yield loss

${ }^{5}$ This study was conducted in the same field used by Lindquist et al. (20) While the existence of Verticillium was not examined in this study, we assume velvetleaf was infected.
}

theophrasti Medicus \#3 ABUTH; soybean, Glycine max (L.) Merr. 'Evans'; corn, Zea mays L.

Additional index words. Demography, economic threshold, ABUTH.

\section{INTRODUCTION}

Recent public concern over nonpoint source pollution resulting from the application of pesticides has stimulated much discussion and research (23) on the potential of economic thresholds as a method of reducing herbicide use. Single year economic thresholds are based upon expected crop yield loss resulting from weed interference within a growing season. Economic threshold theory necessitates leaving weeds in the field. Unfortunately, weeds left uncontrolled based upon a single year economic threshold decision may produce large numbers of seed even under very poor environmental conditions, resulting in a potentially large seedbank population size in subsequent years. Therefore, long-term population dynamics must be considered in economic threshold calculations. Economic optimum thresholds $(\text { EOT })^{4}$ are calculated based on expected net returns over multiple years of simulated weed population dynamics, weed-crop interference, and weed management $(7,8,9,17)$.

Modeling the population dynamics and economics of weed management in crops also may be used to identify strategies for reducing long-term herbicide use $(5,10,13,34)$. Several researchers have modeled the economics of annual weeds in cereals $(5,9,10,13,34)$ and weed competition in soybeans $(1,35$, 36 ), but modeling the population dynamics and economics of weed management in the corn-soybean rotation common to the north central United States has received little attention to date.

Velvetleaf is a major weed in corn and soybean (33), infesting more than 9 million ha of soybean in the United States at an annual control cost of $\$ 225$ million (31). Velvetleaf is highly susceptible to Verticillium wilt (29). A recent study on the demographics of velvetleaf in soybean reported that velvetleaf survival, seed production and competitive ability were substantially reduced as a result of Verticillium (20). Another study of velvetleaf competition and seed production in corn found no yield loss across velvetleaf densities (3) 3 . In contrast, up to $47 \%$ corn yield loss due to velvetleaf interference was observed in Italy (28). Moreover, Verticillium infected velvetleaf seed production in corn (3) was less than $10 \%$ of that measured in Italy (38). A comparison of the population dynamics and economics of a Verticillium-infected population with the dynamics of an uninfected population may provide insight into the potential benefit of biological control of velvetleaf with this pathogen.

The objectives of this research were to: 1) determine the EOT density of velvetleaf seedlings for a corn-soybean rotation, 
2) compare the simulated economic returns and long-term herbicide use resulting from a Verticillium infected and an uninfected velvetleaf population under an EOT management strategy, and 3) evaluate the potential increase in economic return and reduction in long-term herbicide use when alternate management strategies are utilized to manipulate the most sensitive model parameters.

\section{MATERIALS AND METHODS}

The model and assumptions. The model was used to calculate velvetleaf population dynamics and economic return from crop production over a $20 \mathrm{yr}$ period. Population dynamics were calculated on a square meter basis, then scaled up to hectares for economic calculations. Therefore, the model assumed a spatially homogenous weed population. Corn was grown in even years (including year $\mathrm{t}=0$ ), and soybean in odd years. Velvetleaf was assumed to be the only weed in the system, and bentazon at 1.1 $\mathrm{kg} \mathrm{ha}^{-1}$ the only option available for a threshold weed management strategy in both corn and soybean. The decision to use bentazon was made if the seedling population density exceeded a specified threshold density.

Seedling recruitment. To simplify calculations, the model operated on a one-year time step, so seedling emergence was assumed to occur in a single cohort simultaneous with crop emergence. Lindquist et al. (20) provided an estimate of density independent emergence, so velvetleaf seedling population density $\left(N_{\mathrm{sl}}{ }^{4}\right.$, seedlings $\left.\mathrm{m}^{-2}\right)$ was calculated as:

$$
N_{\mathrm{sl}}=N_{\mathrm{sb}} \cdot E_{\mathrm{m}}
$$

where $N_{\mathrm{sb}}{ }^{4}$ is the seedbank population density and $E_{\mathrm{m}}$ is the proportion of the seedbank that emerges. Emergence was assumed to be constant across cropping years. Possible variation in the proportion of the seedbank that emerges resulting from an age-structured seedbank population or from seed buried at different depths in soil was not included in the model.

Seedling survivorship. Several researchers have reported that velvetleaf seedling survivorship is density independent $(2,20$, $25)$, so mature velvetleaf population density $\left(N_{\mathrm{m}}{ }^{4}\right.$, plants $\left.\mathrm{m}^{-2}\right)$ was calculated as follows:

$$
N_{\mathrm{m}}=N_{\mathrm{sl}} \cdot S_{\mathrm{sl}} \cdot\left(1-E_{\mathrm{f}} \cdot q\right)
$$

where $S_{\mathrm{Sl}}$ is the proportion of velvetleaf seedlings surviving to maturity in the absence of weed control, $E_{\mathrm{f}}$ is the herbicide efficacy (the proportion of seedlings killed by the herbicide), and $q^{4}$ is a binary term equal to 0 if no herbicide was used and 1.0 if herbicide was used. Because emergence was assumed to occur in a simultaneous cohort, survivorship as a function of time of emergence was not included in the model. Moreover, velvetleaf survivorship was assumed to be independent of crop species present.
Seed production. Velvetleaf seed production $\left(N_{\mathrm{p}(\mathrm{i})}{ }^{4}\right.$, seeds $\left.\mathrm{m}^{-2}\right)$ in mixture with crop species $i$ was modeled as a function of mature weed density using the negative exponential:

$$
N_{\mathrm{p}(\mathrm{i})}=N_{\mathrm{m}} \cdot\left(P_{\mathrm{m}(\mathrm{i})} \cdot\left(\exp \left(-P_{\mathrm{a}(\mathrm{i})} \cdot N_{\mathrm{m}}\right)\right)\right) \cdot\left(1-P_{\mathrm{r}} \cdot q\right)
$$

where $P_{\mathrm{m}(\mathrm{i})}$ is the maximum seed production (seeds plant ${ }^{-1}$ ) in the presence of crop species $i, P_{\mathrm{a}(\mathrm{i})}$ is the rate of decay parameter for velvetleaf seed production in mixture with crop $i, P_{\mathrm{r}}$ is the reduction in seed production of weeds that escaped mortality as seedlings if herbicide was applied, and $q$ is the binary term as described above. Constant crop density was assumed.

Seed production was the only density-dependent demographic process incorporated into the model. Simulated seedbank populations can reach an equilibrium density, oscillate, or continue exponential growth depending on the seed production function. Using equation 3 , seed production (seeds $\mathrm{m}^{-2}$ ), as a function of mature velvetleaf density, increases to a maximum then declines toward zero as a lower asymptote. This reduction of seed production at high velvetleaf density may allow for a decline in the seedbank over time. A 'humped' seed production function may result if a certain biomass must be reached before seed production can occur. This is a requirement for velvetleaf $(25,32,38)$, but may not be the case for other weed species. Thus, in the construction of weed population dynamic models, considerable attention must be given to the consequences of the equation selected to represent each demographic process (24).

Seedbank dynamics. Velvetleaf spring seedbank population in year $t+1\left(N_{\mathrm{sb}(t+1)}\right.$, seeds $\left.\mathrm{m}^{-2}\right)$ was calculated as follows:

$$
N_{\mathrm{sb}(\mathrm{t}+1)}=\left(\left(N_{\mathrm{sb}(\mathrm{t})}-N_{\mathrm{sl}}\right) \cdot S_{\mathrm{sb}}+N_{\mathrm{p}(\mathrm{i})}\right) \cdot S_{\mathrm{w}}
$$

where $S_{\mathrm{sb}}$ is the proportion of ungerminated seeds in the spring seedbank (year $t$ ) that survive in soil through the growing season, and $S_{\mathrm{w}}$ is the overwintering survival of the autumn seedbank (following seed rain). Both $S_{\mathrm{sb}}$ and $S_{\mathrm{w}}$ were assumed to be independent of crop species present.

Crop yield loss. Percent crop yield loss resulting from velvetleaf competition $\left(Y L_{(\mathrm{i})}\right)^{4}$ is modeled using the rectangular hyperbola equation (6):

$$
Y L_{(\mathrm{i})}=\left(\frac{Y L_{\mathrm{a}(\mathrm{i})} \cdot N_{\mathrm{m}}}{1+\frac{Y L_{\mathrm{a}(\mathrm{i})} \cdot N_{\mathrm{m}}}{Y L_{\mathrm{b}(\mathrm{i})}}}\right) \cdot\left(1-Y L_{\mathrm{r}} \cdot q\right)
$$

where $Y L_{\mathrm{a}(\mathrm{i})}$ is the initial slope of the yield loss function (\% yield loss as density approaches zero) for crop $i, Y L_{\mathrm{b}(\mathrm{i})}$ is the maximum (\%) yield loss of crop $i, Y L_{\mathrm{r}}$ is the reduction in yield loss resulting from the reduced interference of weed escapes when herbicide was applied, and $q$ is the binary term as described above.

Economic returns. The expected economic return obtained for the production of crop $i$ in any given year $\left(E R_{(\mathrm{i})}{ }^{4}, \$ \mathrm{ha}^{-1}\right)$ was calculated as: 
Table 1. Parameter definitions, values used in the model for each cropping year (Verticillium-infected I, and uninfected II), sensitivity coefficient (parameter value increased Q1, or decreased Q2, by $10 \%$ ), and reference where the parameter estimate was obtained.

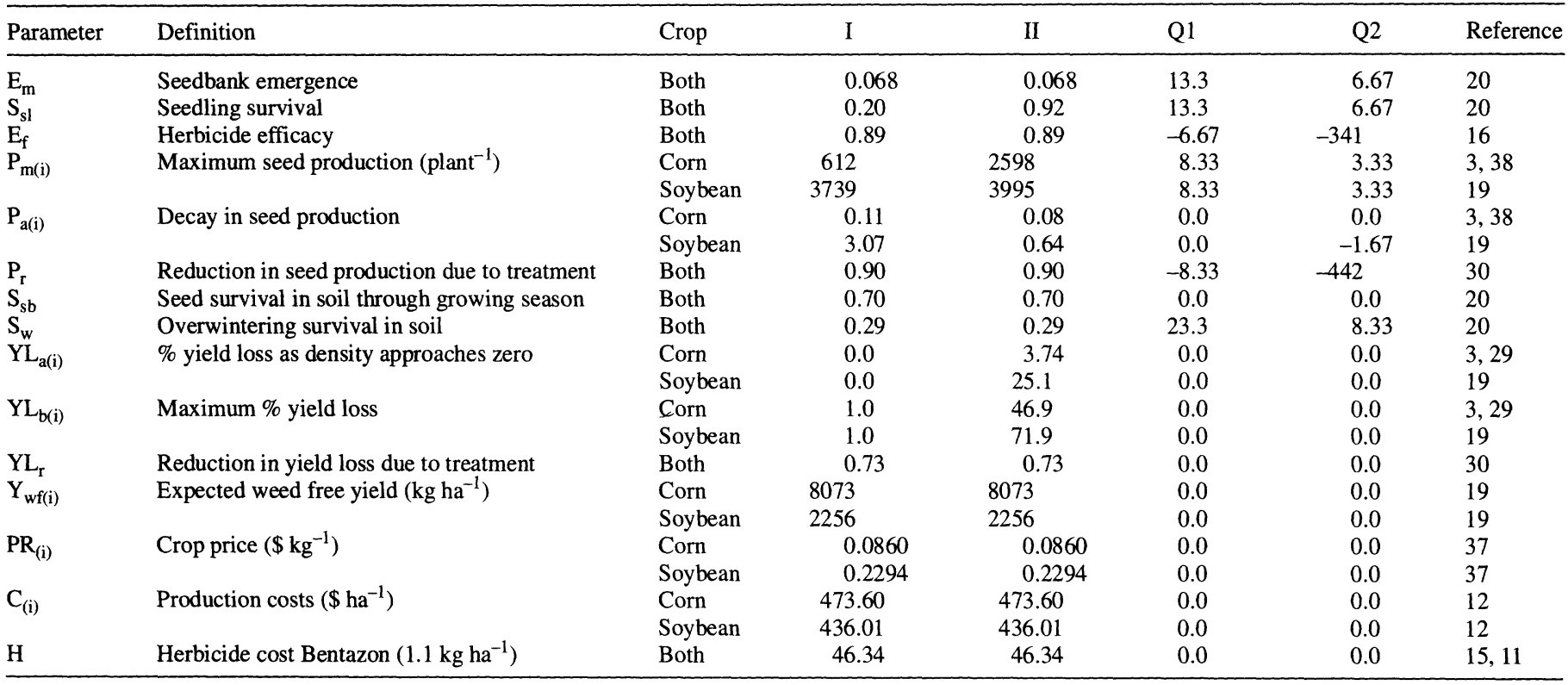

$$
E R_{(\mathrm{i})}=Y_{\mathrm{wf(i)}} \cdot\left(1-Y L_{(\mathrm{i})} / 100\right) \cdot P R_{(\mathrm{i})}-C_{(\mathrm{i})}-(H \cdot q)
$$

where $Y_{\mathrm{wf}(\mathrm{i})}$ is the expected weed free crop $(i)$ yield $\left(\mathrm{kg} \mathrm{ha}^{-1}\right)$, $P R_{(\mathrm{i})}$ is the price obtained for crop $i\left(\$ \mathrm{~kg}^{-1}\right), C_{(\mathrm{i})}$ is the production costs $\left(\$ \mathrm{ha}^{-1}\right), H$ is the total cost of the herbicide and its application $\left(\$ \mathrm{ha}^{-1}\right)$, and $q$ is the binary term as described above. Expected economic return over the 20 yr period was summarized using an annualized net return $\left(\mathrm{ANR}^{4}, \$ \mathrm{ha}^{-1}, 18\right)$, defined as:

$$
A N R=\left[\sum_{t=1}^{20} E R_{(\mathrm{i}) \mathrm{t}} \cdot(1+0.04)^{-t}\right] \cdot\left[\frac{0.04}{\left(1-(1+0.04)^{-t}\right)}\right]
$$

where $t$ is year of simulation, and 0.04 is the annual discount rate, representing the real interest rate because crop price and cost of production over the simulation period were not adjusted for inflation.

Parameter estimates. The model requires the initial seedbank density (seeds $\mathrm{m}^{-2}$, in year $t=0$ ) and estimates for 22 parameters. A list of the model parameters, their definition, values, and their source was provided in Table 1. Two values were listed for each parameter, one representing the case where Verticillium wilt infects the velvetleaf population (I), and the other representing an uninfected velvetleaf population (II).

Survivorship of an uninfected velvetleaf population was estimated from compiled data (19). Estimates of velvetleaf seed production and yield loss resulting from a Verticillium-infected population were obtained by fitting equations 3 and 5 to the data of Bussler (3) for corn and Lindquist (19) for soybean. Parameter estimates for velvetleaf seed production and yield loss resulting from an uninfected population were obtained by fitting equations
3 and 5 to the data of Zanin and Sattin (38) for corn, and to data compiled from a number of sources (see 19) for soybean. Estimates of the expected weed-free yields of corn and soybean were based upon the average corn and soybean production from 10 south-central Minnesota counties in 1991 and 1992 (37). Crop price estimates used in the model were based upon the average price obtained by Minnesota farmers over the five years from 1988 to 1992 (37). Costs of production include cash costs (seed, fertilizer, fuel and maintenance) and fixed costs (machinery ownership, land interest, and taxes) less a gain from government programs (for corn only), as estimated by Fuller et al. (12). Herbicide cost was estimated based upon cost of product (15), application costs (11), and cost of crop oil concentrate.

\section{RESULTS AND DISCUSSION}

Economic optimum threshold. The model was used to determine the long-term EOT velvetleaf seedling density for a cornsoybean rotation. For this analysis we assumed the absence of Verticillium, and used the parameter estimates for uninfected velvetleaf populations (Table 1, II). The model was run at two initial seedbank densities ( 1 and 100 seeds $\mathrm{m}^{-2}$ ) and over a complete range of threshold densities from zero to four seedlings $\mathrm{m}^{-2}$ (using increments of 0.025 seedlings $\mathrm{m}^{-2}$ ). The EOT was determined from simulation output as the threshold density at which ANR was maximized (Figure 1). Simulation results show ANR after $20 \mathrm{yr}$ of simulation was maximum at 0.025 and 0.15 seedlings $\mathrm{m}^{-2}$ when initial seedbank densities were 1 and 100 seeds $\mathrm{m}^{-2}$, respectively. These values were close to the 0.03 weeds $\mathrm{m}^{-2}$ EOT reported by Bauer and Mortensen (1) for velvetleaf in soybean, assuming an initial seedbank population of 100 seeds $\mathrm{m}^{-2}$. 


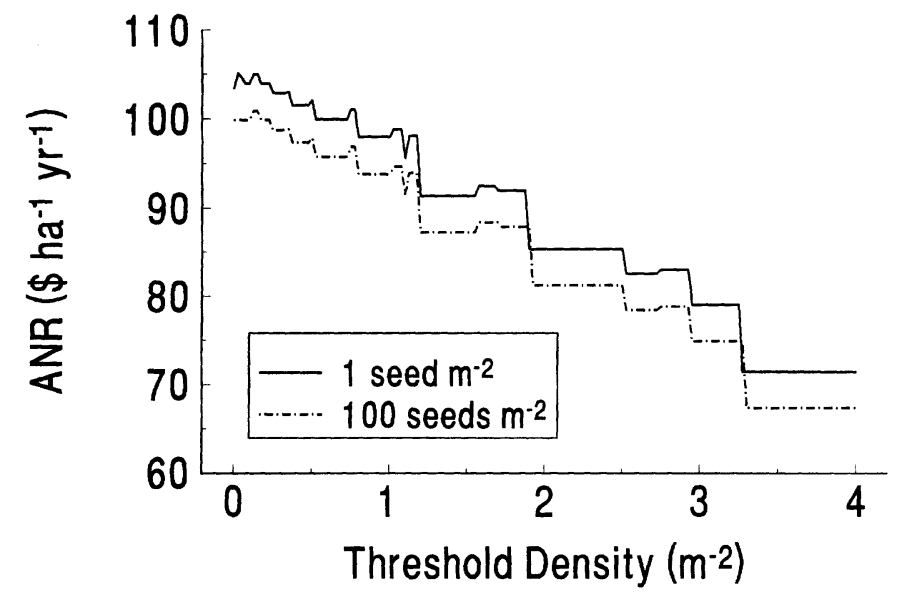

Figure 1. Simulated annualized net return (ANR) as a function of threshold density for initial seedbank densities of 1 and 100 seeds $\mathrm{m}^{-2}$.

Population dynamics. The model was used to compare the simulated population dynamics of a Verticillium-infected velvetleaf population with that of an uninfected population without weed control in a corn-soybean rotation. Simulation results suggest an annually infected velvetleaf population will oscillate stably around a seedbank density of about 80 seeds $\mathrm{m}^{-2}$ (Figure 2a). Simulated dynamics of an uninfected velvetleaf population showed diverging oscillations between 400 and 4000 seeds $\mathrm{m}^{-2}$ (Figure 2b). The periodicity of these oscillations was $4 \mathrm{yr}$ for both infected and uninfected velvetleaf populations. Because no weed control was imposed for these simulations, the period of oscillation was determined by the form of the velvetleaf seed production function and its parameter estimates that vary depending upon the crop grown. Once the velvetleaf population builds to a sufficiently high level, seed production declines precipitously, resulting in a reduced population the following year.

Velvetleaf population dynamics were then simulated to evaluate the impact of a threshold weed management strategy (Figure 3 ). Initial seedbank density for the simulations was 100 seeds $\mathrm{m}^{-2}$, and $\mathrm{N}_{\mathrm{T}}{ }^{4}$ was the threshold seedling density for control. Under a management strategy using the higher threshold densities $\left(\mathrm{N}_{\mathrm{T}}=0.15\right.$ and 1.0), velvetleaf seedling populations are almost always above $\mathrm{N}_{\mathrm{T}}$ (therefore bentazon is nearly always used). In years that the seedling population falls below $\mathrm{N}_{\mathrm{T}}$, seed production is high, resulting in a peak in seedbank population the following year. Under the economic optimum threshold density of 0.025 seedlings $\mathrm{m}^{-2}$, velvetleaf seedbank populations were reduced to low levels due to nearly constant control, but never to zero (Figure 3). These results suggest that once a seedbank is established, eradication may be impossible, even when Verticillium always infects the velvetleaf populations.

Lindquist et al. (20) suggested that a Verticillium-infected velvetleaf population did not cause soybean yield loss, indicating that threshold management was not necessary if Verticillium was known to be present. However, Sickinger (29) suggested that Verticillium may be capable of damaging velvetleaf only in years
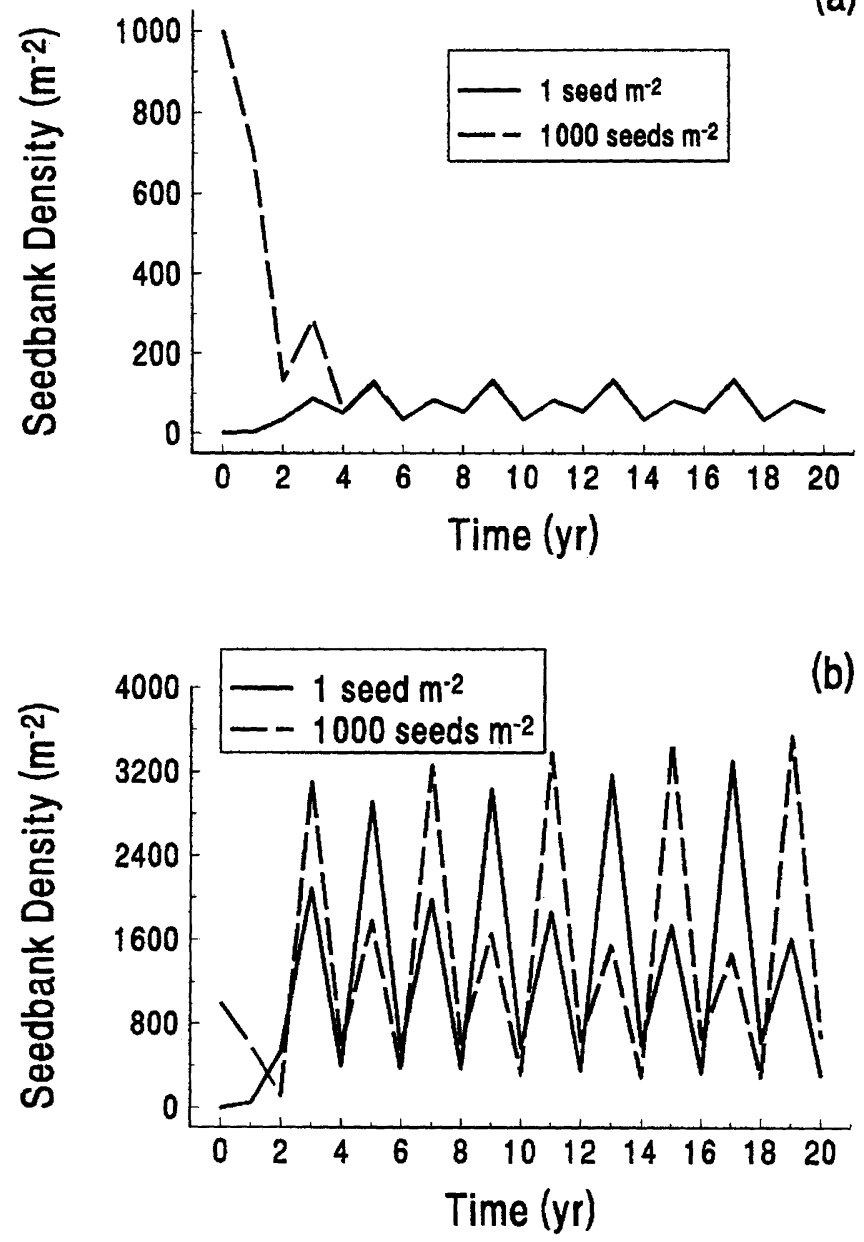

Figure 2. Simulated population dynamics of a Verticillium-infected velvetleaf population (a) and an uninfected population (b) without weed control. Initial seedbank densities in year $\mathrm{t}=0$ are indicated in the legend.

when environmental conditions are optimum for growth of the Verticillium pathogen. The importance of Verticillium may therefore be temporally variable, yet its existence may assist in reducing long-term velvetleaf population densities, and reduce the need for herbicide use over time.

The model was used to evaluate the extent to which ANR could be increased and long-term herbicide applications reduced in the presence of temporally variable Verticillium infection. An initial velvetleaf seedbank density of 100 seeds $\mathrm{m}^{-2}$ and an economic threshold density of 0.025 seedlings $\mathrm{m}^{-2}$ were assumed. Verticillium was assumed to be present in all years, but could only infect the velvetleaf population in a specified proportion $(0,10,20, \ldots 100 \%)$ of the years. Which years the infections occurred were randomly assigned by the model over 20 iterations. Simulation results (Figure 4) indicated ANR was increased up to $19 \%$ and the number of years herbicide was necessary was reduced up to $35 \%$ if Verticillium was infectious in $100 \%$ of the years. Thus, Verticillium may be a very effective biological 
WEED SCIENCE
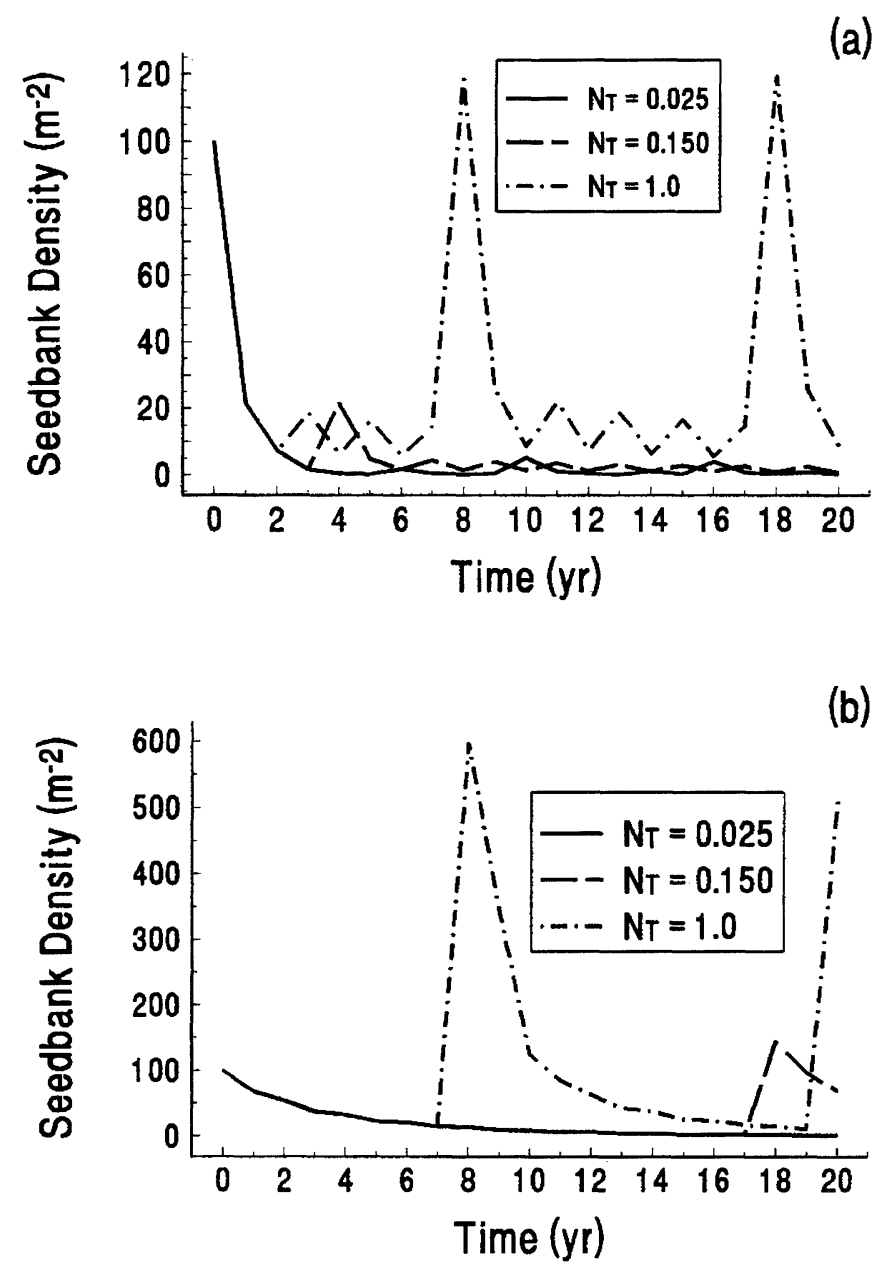

Figure 3. Simulated population dynamics of a Verticillium-infected (a) and an uninfected (b) velvetleaf population under a threshold weed control strategy. $\mathrm{N}_{\mathrm{T}}$ represents the threshold seedling density $\left(\mathrm{m}^{-2}\right)$ at which bentazon was used.

control agent against velvetleaf if its activity can be regulated. Research on the potential of Verticillium for biological control of velvetleaf has been conducted $(14,29)$. However, several soybean cultivars were found to be susceptible to Verticillium infection in the greenhouse. Lindquist et al. (20) reported that soybean (cv. evans) yield was not affected in the field. Research on Verticillium as a velvetleaf biological control agent should continue.

Sensitivity analysis. Model simulations have shown that the effect of a pathogen on velvetleaf population dynamics can have a substantial influence on long-term economic return and herbicide use. It is possible that alternative management strategies may also be employed to obtain the same results.

Sensitivity analysis was conducted to determine which parameter estimates had the greatest influence on the change in predicted EOT density. This procedure involves repeated simulations in which each parameter was increased and reduced by $10 \%$, keeping all other parameters constant. A sensitivity coefficient $(Q)^{4}$ was calculated as the ratio of relative change $(\Delta)$

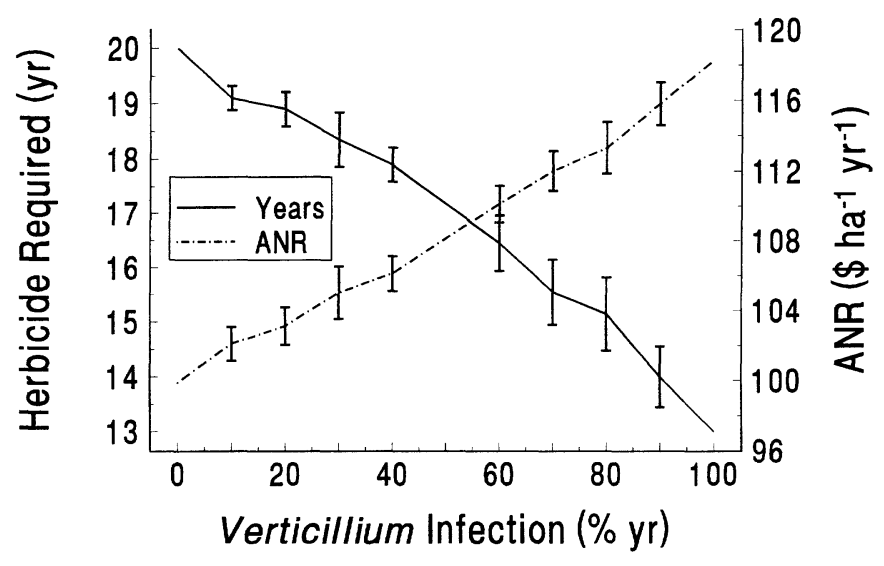

Figure 4. Number of years herbicide was required to control velvetleaf, and annualized net return (ANR) as a function of the percent of years in which Verticillium was infectious. Years in which infection occurred were assigned randomly, error bars indicate \pm one standard error of the mean across 20 iterations of model simulation. An initial seedbank density of 100 seeds $\mathrm{m}^{-2}$ was assumed.

in EOT to the relative change $(\Delta)$ in the parameter estimate (13, 21):

$$
Q=\frac{(\Delta \text { EOT } / \text { EOT })}{\Delta \text { Parameter } / \text { Parameter }}
$$

Parameters with large absolute $Q$ values have a large impact on EOT. These parameters may be targeted for further investigation to determine whether a realistic change in the parameter value resulting from a management strategy would improve economic return and reduce long-term herbicide use.

Sensitivity analysis was conducted for initial seedbank densities of 1.0 and 100 seeds $\mathrm{m}^{-2}$. Results varied only slightly across densities, so the $Q$ values obtained from simulations using an initial seedbank of 100 seeds $\mathrm{m}^{-2}$ were listed in Table 1. Parameter estimates with the largest absolute $Q$ values were: the reduction in seed production due to control $\left(P_{\mathrm{r}}\right)$, herbicide efficacy $\left(E_{\mathrm{f}}\right)$, overwintering survival of seeds $\left(S_{\mathrm{w}}\right)$, seedling survival $\left(S_{\mathrm{sl}}\right)$, the proportion of the seedbank emerging $\left(E_{\mathrm{m}}\right)$, and the maximum seed production parameters $\left(P_{\mathrm{m}(\mathrm{i})}\right)$.

Further analysis was conducted to evaluate the impact of specific changes in the above listed parameters on ANR over 20 yr of simulation and the number of years in which herbicide use was necessary under the EOT management strategy. Simulations were conducted across three initial seedbank densities $(1.0,10$, and 100 seeds $\mathrm{m}^{-2}$ ) assuming an EOT density of 0.025 seedlings $\mathrm{m}^{-2}$. All parameters were held constant except the parameter of interest, which was varied according to an estimated change resulting from a management practice. The results of this analysis (Table 2) may provide hypotheses concerning where research might be directed to reduce herbicide use while maintaining or even improving economic returns.

Herbicide efficacy is most often estimated based upon visual estimates of weed biomass in a treated plot relative to biomass 
Table 2. Simulated annualized net return (ANR) after $20 \mathrm{yr}$ and number of years of weed control (yr) under an EOT strategy of 0.025 seedlings $\mathrm{m}^{-2}$ as influenced by initial seedbank density (seeds $\mathrm{m}^{-2}$ ) and changes in five parameter values.

\begin{tabular}{|c|c|c|c|c|c|c|c|}
\hline \multirow[b]{2}{*}{ Parameter } & \multirow[b]{2}{*}{ Value } & \multicolumn{2}{|c|}{1.0 seed } & \multicolumn{2}{|c|}{10 seeds } & \multicolumn{2}{|c|}{100 seeds } \\
\hline & & ANR & $\mathrm{yr}$ & ANR & $\mathrm{yr}$ & ANR & $\mathrm{yr}$ \\
\hline & & $\$ \mathrm{ha}^{-1}$ & & $\$ \mathrm{ha}^{-1}$ & & $\$ \mathrm{ha}^{-1}$ & \\
\hline Table $1^{\mathrm{a}}$ & & 105.13 & 19 & 104.34 & 19 & 99.85 & 20 \\
\hline \multirow[t]{4}{*}{$\mathrm{S}_{\mathrm{sl}}$} & 0.8 & 107.19 & 18 & 104.76 & 19 & 102.30 & 19 \\
\hline & 0.7 & 107.62 & 18 & 105.21 & 19 & 103.05 & 19 \\
\hline & 0.5 & 110.17 & 17 & 109.18 & 17 & 106.05 & 18 \\
\hline & 0.2 & 117.17 & 14 & 114.37 & 15 & 113.16 & 15 \\
\hline \multirow[t]{4}{*}{$S_{w}$} & 0.25 & 107.19 & 18 & 104.79 & 19 & 102.26 & 19 \\
\hline & 0.20 & 109.50 & 17 & 107.04 & 18 & 104.85 & 18 \\
\hline & 0.15 & 112.16 & 16 & 109.57 & 17 & 107.58 & 17 \\
\hline & 0.10 & 116.62 & 14 & 114.05 & 15 & 112.04 & 15 \\
\hline \multirow[t]{5}{*}{$\Delta \mathrm{P}_{\mathrm{m}}(\%)$} & -5 & 105.37 & 19 & 104.44 & 19 & 100.14 & 20 \\
\hline & -10 & 105.45 & 19 & 104.60 & 19 & 100.39 & 19 \\
\hline & -20 & 107.34 & 18 & 104.90 & 19 & 102.37 & 19 \\
\hline & -40 & 109.57 & 17 & 107.08 & 18 & 104.81 & 18 \\
\hline & -80 & 116.89 & 14 & 115.72 & 14 & 111.99 & 15 \\
\hline \multirow[t]{4}{*}{$\mathrm{E}_{\mathrm{f}}$} & 0.91 & 107.27 & 18 & 104.87 & 19 & 102.60 & 19 \\
\hline & 0.93 & 107.84 & 18 & 107.08 & 18 & 103.80 & 19 \\
\hline & 0.95 & 110.14 & 17 & 109.29 & 17 & 106.38 & 18 \\
\hline & 0.97 & 112.39 & 16 & 111.61 & 16 & 109.02 & 17 \\
\hline \multirow[t]{4}{*}{$P_{r}$} & 0.92 & 107.20 & 18 & 104.84 & 19 & 102.33 & 19 \\
\hline & 0.94 & 109.32 & 17 & 106.87 & 18 & 104.67 & 18 \\
\hline & 0.96 & 110.00 & 17 & 109.19 & 17 & 107.13 & 17 \\
\hline & 0.98 & 112.25 & 16 & 111.41 & 16 & 109.56 & 16 \\
\hline
\end{tabular}

a Simulation output for the unchanged parameter values (uninfected velvetleaf) listed in Table 1.

present in an untreated check plot. In the model, herbicide efficacy was assumed to be the proportion of seedlings killed, and therefore does not fully account for the demographic impact of the herbicide on weed populations. To adjust for this weakness, reproduction and competitiveness of surviving seedlings were reduced by constant proportions $\left(P_{\mathrm{r}}\right.$ and $\left.Y L_{\mathrm{r}}\right)$ if the herbicide was used. A comparison of velvetleaf seed production $\left(\right.$ plant $\left.^{-1}\right)$ in herbicide-treated plots with that in untreated plots suggested a substantial reduction in seed production in treated plots (30). By changing $E_{\mathrm{f}}$ from 0.89 to 0.97 or $P_{\mathrm{r}}$ from 0.9 to 0.98 , simulated ANR was increased by $10 \%$, and long-term herbicide use was reduced by $20 \%$ (Table 2 ).

The overwintering survival parameter $\left(S_{\mathrm{w}}\right)$ may be manipulated by mechanically removing seeds during harvest or by encouraging herbivorous animals that prefer weed seeds to inhabit nearby areas (e.g., field edges or fencelines). Few quantitative data useful for estimating $S_{\mathrm{w}}$ are available for most weed species. Simulation results (Table 2) suggest that ANR would increase as much as $12 \%$ and the number of years of control reduced up to $25 \%$ if $S_{\mathrm{w}}$ was reduced to $10 \%$ from the $29 \%$ observed by Lindquist et al. (20).

Velvetleaf seedling survival can be reduced as the result of crop interference, cultivation, or biological control. Simulation results (Table 2) indicated that reducing the proportion of seed- lings surviving from 0.92 to 0.2 increased ANR up to $13 \%$ and reduced the number of years in which control was necessary by $25 \%$ across all initial seedbank densities.

Weed biomass production may be reduced through increased crop competitiveness $(4,22,27)$ or by optimizing planting density and spatial arrangement (4). Because velvetleaf seed production is correlated with biomass (26), the maximum seed production $\left(P_{\mathrm{m}(\mathrm{i})}\right)$ of velvetleaf may also be reduced. Results in Table 2 suggest that ANR could be increased as much as $12 \%$, and the number of years of control reduced $25 \%$ if the maximum seed production parameter value was reduced $80 \%$ (to $\approx 700$ seeds plant ${ }^{-1}$ ).

Bauer and Mortensen (1) found little economic gain of the EOT strategy over the zero threshold management strategy (i.e., continuous herbicide use), and questioned whether the gain would balance the overall costs required to calculate and implement the EOT strategy. Results shown in Figure 1 might lead to a similar conclusion. However, this simulation study has shown that linking an EOT strategy with alternative weed management practices may substantially increase long-term economic returns, while reducing herbicide use. Further research on the influence of Verticillium and other biological control agents, cultivation, crop density and spatial arrangement, and mechanical seed removal on weed seedling survival, seed production, and competi- 
tiveness is critical if the EOT and alternative weed management strategies are to become viable field practices.

\section{ACKNOWLEDGEMENTS}

We thank Drs. D. Andow, B. Durgan, F. Forcella, R. King, and three reviewers for their valuable comments on the manuscript, and B. Bussler for providing his corn yield loss and velvetleaf seed production data. This research was supported in part by USDA-ARS Cooperative Agreement titled "Validation of Weed Management Expert Systems for Corn and Soybeans in Minnesota."

\section{LITERATURE CITED}

1. Bauer, T. A. and D. A. Mortensen. 1992. A comparison of economic and economic optimum thresholds for two annual weeds in soybeans. Weed Technol. 6:228-235.

2. Bazzaz, F. A., D. D. Ackerly, F. I. Woodward, and L. Rochefort. 1992. $\mathrm{CO}_{2}$ enrichment and dependence of reproduction on density in an annual plant and a simulation of its population dynamics. J. Ecol. 80:643-651.

3. Bussler, B. H. 1993. Corn interactions with common cocklebur and velvetleaf. Ph.D. Thesis, University of Minnesota, St. Paul MN, 103 p.

4. Burnside, O. C. 1979. Soybean (Glycine max) growth as affected by weed removal, cultivar, and row spacing. Weed Sci. 27:562-565.

5. Cousens, R., C. J. Doyle, B. J. Wilson, and G. W. Cussans. 1986. Modelling the economics of controlling Avena fatua in winter wheat. Pestic. Sci. 17:1-12.

6. Cousens, R. 1985. A simple model relating yield loss to weed density. Ann. Appl. Biol. 107:239-252.

7. Cousens, R. 1986. The use of population models in the study of the economics of weed control. Proc. European Weed Res. Soc. Symp., Economic Weed Control, 269-276.

8. Cousens, R. 1987. Theory and reality of weed control thresholds. Plant Prot. Quart. 2:13-20.

9. Doyle, C. J., R. Cousens, and S. R. Moss. 1986. A model of the economics of controlling Alopecurus myosuroides Huds. in winter wheat. Crop Prot. 5:143-150.

10. Firbank, L. G. and A. R. Watkinson. 1986. Modelling the population dynamics of an arable weed and its effects upon crop yield. J. Appl. Ecol. 23:147-159.

11. Fuller, E. I., B. Lazarus, and D. Nordquist. 1990. Minnesota farm machinery economic cost estimates. Univ. Minnesota Extension Service. AG-FO-2380.

12. Fuller, E., B. Lazarus, and L. Carrigan. 1991. What to grow in 1991. Crop budgets for soil area 4. Univ. Minnesota Extension Service. AG-FS-0937-A.

13. Gonzalez-Andujar, J. L. and C. Fernandez-Quintanilla. 1991. Modelling the population dynamics of Avena sterilis under dry-land cereal cropping systems. J. Appl. Ecol. 28:16-27.

14. Green, R. J. and G. L. Wiley. 1987. Verticillium dahliae as a biocontrol agent of velvetleaf, Abutilon theophrasti. Can. J. Plant Path. 9:81.

15. Gunsolus, J. L., B. R. Durgan, R. L. Becker, A. G. Dexter, D. D. Buhler, and D. L. Wyse. Cultural and chemical weed control in field crops- 1992. University of Minnesota Extension Service. AG-BU-3157-S.

16. Harrison, S. K., L. M. Wax, and L. E. Bode. 1986. Influence of adjuvants and application variables on postemergence weed control with bentazon and sethoxydim. Weed Sci. 34:462-466.
17. Jordan, N. 1992. Weed demography and population dynamics: Implications for threshold management. Weed Technol. 6:184-190.

18. King, R. P., D. W. Lybecker, E. E. Schweizer, and R. L. Zimdahl. 1986. Bioeconomic modeling to simulate weed control strategies for continuous corn (Zea mays). Weed Sci. 34:972-979.

19. Lindquist, J. L. 1994. Population dynamics and economics of velvetleaf (Abutilon theophrasti Medik.) in a corn-soybean rotation. M.S. Thesis, University of Minnesota, St. Paul MN 55108.

20. Lindquist, J. L. B. D. Maxwell, D. D. Buhler, and J. L. Gunsolus. 1995. Velvetleaf (Abutilon theophrasti) recruitment, survival, seed production, and interference in soybean (Glycine max). Weed Sci. 43:226-232.

21. Maxwell, B. D., M. V. Wilson, and S. R. Radosevich. 1988. Population modeling approach to evaluating leafy spurge (Euphorbia esula) development and control. Weed Technol. 2:132-138.

22. McWhorter, C. G. and E. E. Hartwig. 1972. Competition of johnsongrass and cocklebur with six soybean varieties. Weed Sci. 20:56-59.

23. Norris, R. F. 1992. Ecological perspectives on utility of thresholds for weed management. Weed Technol. 6:182-183.

24. Pacala, S. W. and J. A. Silander, Jr. 1985. Neighborhood models of plant population dynamics. I. Single-species models of annuals. Amer. Nat. 125:385-411.

25. Pacala, S. W. and J. A. Silander, Jr. 1987. Neighborhood interference among velvetleaf, Abutilon theophrasti, and pigweed, Amaranthus retroflexus. Oikos 48:217-224.

26. Pacala, S. W. and J. A. Silander, Jr. 1990. Field tests of neighborhood population dynamic models of two annual weed species. Ecol. Monogr. 60:113-134.

27. Rose, S. J., O. C. Burnside, J. E. Specht, and B. A. Swisher. 1984. Competition and allelopathy between soybeans and weeds. Agron. J. 76:523-528.

28. Sattin, M., G. Zanin, and A. Berti. 1992. Case history for weed competition/population ecology: Velvetleaf (Abutilon theophrasti) in corn (Zea mays). Weed Technol. 6:213-219.

29. Sickinger, S. M. 1981. The effects of Verticillium dahliae (Kleb.) on velvetleaf (Abutilon theophrasti) and crops. M.S. Thesis, University of Wisconsin, Madison. $141 \mathrm{pp}$.

30. Steckel, L. E., M. S. DeFelice, and B. D. Sims. 1990. Integrating reduced rates of postemergence herbicides and cultivation for broadleaf weed control in soybeans (Glycine max). Weed Sci. 38:541-545.

31. Stoller, E. W., S. K. Harrison, L. M. Wax, E. E. Regnier, and E. D. Nafziger. 1987. Weed interference in soybeans (Glycine max). Rev. Weed Sci. 3:155181.

32. Thrall, P. H., S. W. Pacala, and J. A. Silander, Jr. 1989. Oscillatory dynamics in populations of an annual weed species Abutilon theophrasti. J. Ecol. 77:1135-1149.

33. Warwick, S. I. and L. D. Black. 1988. The biology of Canadian weeds. 90. Abutilon theophrasti. Can. J. Plant Sci. 68:1069-1085.

34. Watkinson, A. R., W. M. Lonsdale, and M. H. Andrew. 1989. Modelling the population dynamics of an annual plant Sorghum intrans in the wet-dry tropics. J. Ecol. 77:162-181.

35. Wilkerson, G. G., J. W. Jones, H. D. Coble, and J. L. Gunsolus. 1990. SOYWEED: A simulation model of soybean and common cocklebur growth and competition. Agron. J. 82:1003-1010.

36. Wiles, L. J. and G. G. Wilkerson. 1992. Modeling competition for light between soybean and broadleaf weeds. Agric. Syst. 35:37-51.

37. Wright, L. (ed.). 1993. Minnesota agriculture statistics 1993. USDA National Statistics Service and the Minnesota Department of Agriculture.

38. Zanin, G. and M. Sattin. 1988. Threshold level and seed production of velvetleaf (Abutilon theophrasti Medicus) in Maize. Weed Res. 28:347-352. 